\title{
Molecular paleoparasitological diagnosis of Ascaris sp. from coprolites: new scenery of ascariasis in pre-Columbian South America times
}

\author{
Daniela Leles, Adauto Araújo, Luiz Fernando Ferreira, Ana Carolina Paulo Vicente', \\ Alena Mayo Iñiguez ${ }^{1 /+}$ \\ Escola Nacional de Saúde Pública-Fiocruz 'Instituto Oswaldo Cruz-Fiocruz, Av Brasil 4365, 21045-900 Rio de Janeiro, RJ, Brazil
}

\begin{abstract}
Paleoparasitological studies using microscopy showed that Ascaris and Trichuris trichiura are the human intestinal parasites most found in archaeological sites. However, in pre-Columbian South American archaeological sites, Ascaris is rare. In this work we standardized a molecular methodology for Ascaris diagnosis directly from ancient $D N A$ retrieved from coprolites. Using cythochrome b gene (142 bp) target, ancient DNA sequences were retrieved from South American samples, negative by microscopy. Moreover, the methodology applied was sensitive enough to detect ancient DNA extracted from 30 Ascaris eggs from an European coprolite. These results revealed a new scenery for the paleodistribution of Ascaris in South America.
\end{abstract}

Key words: Ascaris - molecular paleoparasitological diagnosis - paleodistribution

The human intestinal parasite Ascaris lumbricoides has a cosmopolitan distribution affecting about 1.4 billion people (Lukes et al. 2005). The infection by A. lumbricoides and Trichuris trichiura is one of the most common parasitic associations, probably due to similar transmission cycles and ecological niches occupied. Paleoparasitological studies using microscopy for detecting parasite egg morphology showed that these intestinal parasites are the most commonly found in archaeological material (Bouchet et al. 2003, Gonçalves et al. 2003). Based on data from Gonçalves et al. (2003), the association of A. lumbricoides and T. trichuris eggs was found in over $80 \%$ of European archaeological sites, and in approximately $100 \%$ of ancient remains from the Medieval Age. However, A. lumbricoides eggs in pre-Columbian South American samples are uncommon. The only finding dated of 4,227 Before Present (BP) was found in the Huarmey Valey site, Peru (Patrucco et al. 1983). In contrast, $T$. trichiura eggs are frequently found, having been identified in seven archaeological sites in Brazil, Chile, and Peru, dated of 8000 - 950 BP (Table). The absence of any morphological characteristics to distinguish A. lumbricoides from Ascaris suum eggs (parasite of swine) makes difficult the diagnosis in archaeological material, especially those from the Medieval Age when swine had already been domesticated and lived in close relation to humans (Loreille \& Bouchet 2003, Rocha et al. 2006). Nuclear and mitochondrial DNA sequences have been used as molecular targets in order to discriminate these two related species (Zhu et al. 1999, Anderson 2001, Peng et al. 2005). However, there is no clear genetic definition yet between the two Ascaris species parasitizing humans and those of pigs (Anderson 2001).

Financial support: IOC-Fiocruz, ENSP-Fiocruz, PAPES-Fiocruz, CNPq, CAPES

+ Corresponding author: alena@ioc.fiocruz.br

Received 5 September 2007

Accepted 27 December 2007
The first molecular paleoparasitological study of Ascaris sp. recovered ancient DNA (aDNA) from parasite eggs from samples of the Middle Age site "Place d'Armes" in Namur (XIV century) (Loreille et al. 2001). This successful study was possibly due to a parasite egg high concentration in the latrine coprolites (Loreille $\&$ Bouchet 2003). However, this is not the scenery for South American archaeological sites where the findings of Ascaris sp. are less frequent and the amount of recovered helminth eggs is low. Recently, Iñiguez et al. (2006) succeeded in recovering Enterobius vermicularis aDNA sequences from pre-Columbian samples, opening the possibility of molecular diagnosis using aDNA extracted directly from coprolites. In order to study the temporal and spatial distribution of Ascaris in the past, the objective of this work was to develop a methodology of DNA extraction and Ascaris molecular diagnosis, sensitive enough to be applied to aDNA extracted directly from coprolites.

Six coprolites samples, which four were positive through microscopy for T. trichiura, and all negative for A. lumbricoides, were selected for this study (Ferreira et al. 1980, 1982, 1983, Gonçalves et al. 2003). One sample was from Brazilian Northeast (Toca do Meio, National Park of Serra da Capivara, state of Piauí) and four from the state of Minas Gerais, Southeast region (one from Lapa Pequena, one from Boqueirão Soberbo and two from Gruta do Gentio II archaeological sites), and one sample was from Tulán, San Pedro de Atacama, Chile (Table). The human origin of coprolites was suggested by archaeological context and/or confirmed by the finding of E. vermicularis and T. trichiura eggs, parasites specific to humans (Confalonieri et al 1985, Confalonieri 1988, Iñiguez et al. 2003b). The absence of parasite was considered after examination of forty slides for each sample at magnification of $100 \mathrm{X}$ and $400 \mathrm{X}$. Precautions to prevent contamination by modern DNA and thus to obtain authentic ancient sequences were followed as described elsewhere (Drancourt \& Raoult 2005). Preparation of coprolites samples, aDNA extraction, and polymerase chain reaction (PCR), were carried out at the Paleogenet- 


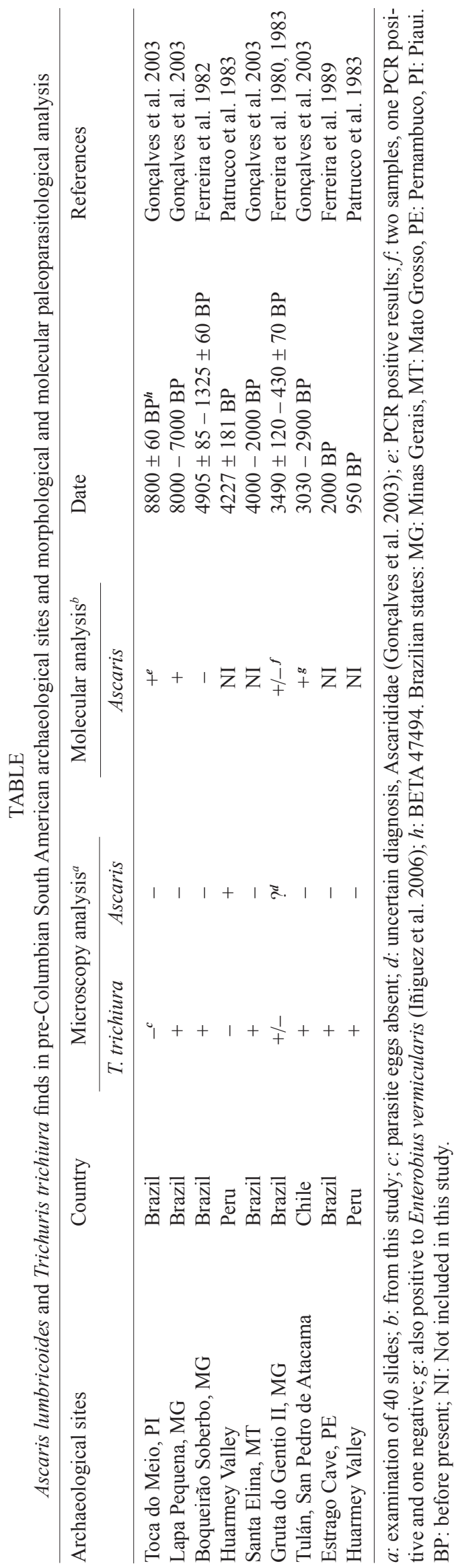

ic room, physically distant from the Laboratory of Molecular Genetic of Microorganisms (IOC/Fiocruz) where electrophoresis, cloning, and sequencing were performed. The isolation of eggs was conducted at Laboratory of Paleoparasitology (ENSP/Fiocruz), geographically distant to the genetic laboratories. Positive PCR controls with modern Ascaris DNA were never included.

The surface of coprolites was removed, and all the samples were ultra violet irradiated (Iñiguez et al. 2003b). The core of coprolites was ground and rehydrated by immersion in a $0.5 \%$ aqueous solution of trisodium phosphate for $72 \mathrm{~h}$, following the technique of Callen and Cameron (1960). The aDNA was extracted by physicalchemical treatment. First $150 \mu \mathrm{l}$ of coprolite sediment were submitted to physical treatment by boiling/freezing, and then proteinase $\mathrm{K}$ digestion and phenol/chloroform method extraction were applied as described (Iñiguez et al. 2006). Alternatively, the commercial QIAamp ${ }^{\circledR}$ DNA Stool Mini Kit (Qiagen) was used after physical treatment. In order to verify the presence of PCR inhibitors, human mitochondrial DNA (mtDNA) fragments (92 bp) were also amplified using conditions described by Pääbo (1990). The molecular target for Ascaris PCR was a 142 bp fragment of cytochrome b (cyt b) mitochondrial gene (Loreille et al. 2001). Re-amplifications and reconstructive PCR reactions were applied when necessary (Golenberg et al. 1996, Iniguez et al. 2003a). After processing all South American coprolites, a sample from Walraversijde site, Belgium (XVI century), which was positive for $A$. lumbricoides by microscopy analyses, was used as positive control (Fernandes et al. 2005). In order to test the sensitivity of this methodology, 30, 50 and 80 eggs were isolated from Walraversijde sample (Figure) and aDNA extraction by physical/chemical treatment was performed. Cloning and nucleotide sequencing of all PCR products were carried out.

The efficiency of the two extractions method employed was quite similar. However, physical treatment seems to be essential to Ascaris aDNA extraction. We were successful in retrieving human DNA from all samples, confirming the lack of PCR inhibitors and corroborating their human origin. Four of six samples, which were microscopically negative for of $A$. lumbricoides eggs, were PCR positive for Ascaris cyt $\mathrm{b}$ segment. The cyt $\mathrm{b}$ fragment was detected in aDNA extracted directly from coprolite sediment as well as from 30 Ascaris isolated eggs. The aDNA sequence analysis of 11 clones samples revealed that all, including from European coprolite sequences, displayed nucleotide $\mathrm{T}$ at position 5522, which is characteristic of the A. lumbricoides (Loreille et al. 2001), whereas a cytosine (C) is displayed in A. suum (Okimoto et al. 1992, access number X54253). New nucleotide substitutions T5492C, C5554G or C5554A, and $\mathrm{T} 5555 \mathrm{C}$ were found in aDNA sequences. The sequence translation using the mitochondrial genetic code revealed one synonymous difference (T20) and two nonsynonymous differences at position 41 . Clones from cyt $\mathrm{b}$ protein fragment from Walraversijde-Belgium, Gruta do Gentio II-Brazil, Toca do Meio-Brazil contain the T41S substitution and a clone from Walraversijde-Belgium the T41N substitution (access number EF439709-24). 


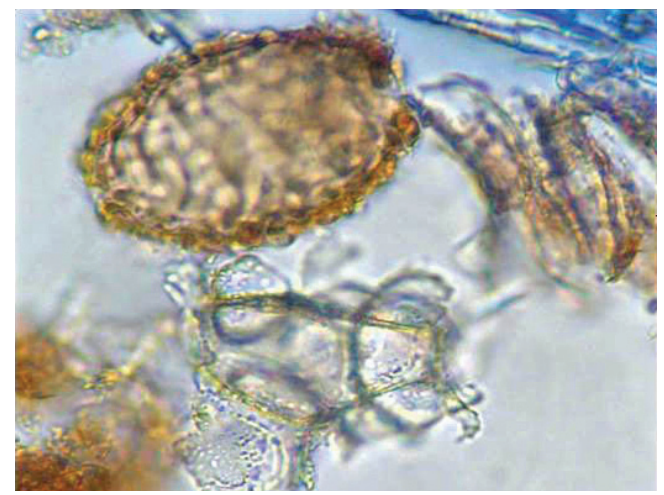

Ascaris eggs (400X) found in latrine from Walraversijde archaeological site, Belgium, dated of XVI century.

In this study, we demonstrated the ability of a methodology to detect Ascaris aDNA without the evidence of parasite eggs and directly from coprolites. The methodology applied was sensitive enough to diagnose the parasite in a sample with only 30 parasite eggs. In spite of few samples analyzed, our results indirectly contributed to design a new panorama of Ascaris paleodistribuition, showing that in fact, this parasite has been present in South America since 8,800 years BP in pre-historic populations from Brazil and Chile. Furthermore, our results suggest that the parasitic association T. trichiura with Ascaris, observed in European historical period and in modern times, also seems to be occurred in South America during pre-Columbian times, possibly with a minor Ascaris prevalence. We are currently working to confirm Ascaris paleodistribuition, including new South America samples and molecular targets. In addition, we are investigating possible factors influencing Ascaris prevalence in pre-Columbian South America, such as pollen of anti-helminths plants and spores of nematophagous fungi.

\section{ACKNOWLEDGEMENTS}

To Koko Otsuki from Laboratory of Molecular Genetic of Microorganisms IOC-Fiocruz, Rio de Janeiro, for their excellent technical assistance and PDTIS/Fiocruz genomic platform for nucleotide sequencing. To Dr. Françoise Bouchet from Université de Reims, France, for providing the European coprolites. To the anonymous rewievers for their sugestions.

\section{REFERENCES}

Anderson TJC 2001. The dangers of using single locus markers in parasite epidemiology: Ascaris as a case study. Trends Parasitol 17: $183-188$.

Bouchet F, Harter S, Le Bailly M 2003. The state of the art of paleoparasitological research in the old world. Mem Inst Oswaldo Cruz 98: 95-101.

Callen O, Cameron TWM 1960. A prehistoric diet as reveled in coprolites. New Sci 8: 35-40.

Confalonieri U 1988. Paleoepidemiologia de Trichuris trichiura na América. In LF Ferreira, A Araújo, U Confalonieri (eds), Paleoparasitologia no Brasil, Editora PEC/ENSP, Rio de Janeiro, p.120-137.

Confalonieri U, Filho BR, Ferreira LF, Araújo A 1985. The experimental approach to paleoparasitology: desiccation of Trichuris trichiura eggs. Paleopathol Newsl 51: 9-11.
Drancourt M, Raoult D 2005. Paleomicrobiology: current issues and perspectives. Nature 3: 23-35.

Fernandes A, Ferreira LF, Gonçalves MLC, Bouchet F, Klein CH, Iguchi T, Sianto L, Araújo A 2005. Intestinal parasite analysis in organic sediments collected from a 16th-century Belgian archeological site. Cad Saude Publica 21: 329-332.

Ferreira LF, Araújo A, Confalonieri U 1980. The finding of eggs and larvae of parasitic helminths in archaeological material from Unai, Minas Gerais, Brazil. Trans R Soc Trop Med Hyg 74: 798-800.

Ferreira LF, Araújo A, Confalonieri U 1982. Untitled note. Paleopathol Newsl 38: 5 .

Ferreira LF, Araújo A, Confalonieri U 1983. The finding of helminth eggs in a Brazilian mummy. Trans R Soc Trop Med Hyg 77: 65-67.

Ferreira LF, Araújo A, Confalonieri U, Lima JMD 1989. Trichuris eggs in human coprolites from archeological site of Furna do Estrago, Brejo da Madre de Deus, Pernambuco. Mem Inst Oswaldo Cruz 84: 581

Golenberg EM, Bickel A, Weihs P, 1996. Effect of highly fragmented DNA on PCR. Nucleic Acids Res 24: 5026-5033.

Gonçalves MLC, Araújo A, Ferreira LF 2003. Human intestinal parasites in the past: New findings and a review. Mem Inst Oswaldo Cruz 98: 103-118.

Iñiguez AM, Araújo A, Ferreira LF, Vicente AC 2003a. Analysis of ancient DNA from coprolites: a perspective with random amplified polymorphic DNA-polymerase chain reaction approach. Mem Inst Oswaldo Cruz 98: 63-65.

Iñiguez AM, Reinhard KJ, Araújo A, Ferreira LF, Vicente ACP 2003b. Enterobius vermicularis: ancient DNA from North and South American human coprolites. Mem Inst Oswaldo Cruz 98: 67-69.

Iñiguez AM, Reinhard K, Gonçalves MLC, Ferreira LF, Araújo A, Vicente ACP 2006. SL1 RNA gene recovery from Enterobius vermicularis ancient DNA in pre-Columbian human coprolites. Int J Parasitol 36: 1419-1425.

Loreille O, Bouchet F 2003. Evolution of ascariasis in humans and pigs: a multi-disciplinary approach. Mem Inst Oswaldo Cruz 98: 39-46.

Loreille O, Roumat E, Verneau O, Bouchet F, Hänni C 2001. Ancient DNA from Ascaris: extraction amplification and sequences from eggs collected in coprolites. Int J Parasitol 31: 1101-1106.

Lukes J, Horak A, Scholz T 2005. Helminth genome projects: all or nothing. Trends Parasitol 21: 265-266.

Okimoto R, Macfarlane JL, Clary DO, Wolstenholme DR 1992. The mitochondrial genomes of two nematodes, Caenorhabditis elegans and Ascaris suum. Genetics 130: 471-498.

Pääbo S 1990. Amplifyng ancient DNA. In MA Innis, DH Gelfand, JJ Sninsky, TJ White (eds), PCR Protocols: A guide to methods and applications, Academic Press, California, p.159-166.

Patrucco R, Tello R, Bonavia D 1983. Parasitological studies of coprolites of pre-hispanic peruvian populations. Curr Anthropol 24: 393-394.

Peng W, Yuan K, Hu M, Zhou X, Gasser RB 2005. Mutation scanningcoupled analysis of haplotypic variability in mitochondrial DNA regions reveals low gene flow between human and porcine Ascaris in endemic regions of China. Electrophoresis 26: 4317-4326.

Rocha GC, Harter-Lailheugue S, Le Bailly M, Araújo A, Ferreira LF, Serra-Freire NM, Bouchet F. 2006. Paleoparasitological remains revealed by seven historic contexts from "Place d'Armes", Namur, Belgium. Mem Inst Oswaldo Cruz 101 (Suppl. II): 43-52.

Zhu X, Chilton NB, Jacobs E, Boes J, Gasser RB 1999. Characterization of Ascaris from human and pig hosts by nuclear ribosomal DNA sequences. Int J Parasitol 29: 469-478. 